\title{
Interdisciplinary panel on the Russian peasantry and notions of 'Russianness', at the Annual Convention of the Association for Slavic, East European, and Eurasian Studies (ASEEES), 8 November 2020
}

\author{
E. Fitzé
}

Eliane Fitzé, PhD candidate at the Chair of Slavic Literature, University of Fribourg (Switzerland). Rue du Criblet 13, 1700, Fribourg, Switzerland.E-mail: eliane.fitze@unifr.ch.

DOI: $10.22394 / 2500-1809-2020-5-4-198-201$

An interdisciplinary group of Russian, American and Swiss scholars held a panel entitled "Imagining Russia through the Countryside: The Russian Peasant and Notions of 'Russianness' Throughout History" at the 2020 Annual Convention of the Association for Slavic, East European, and Eurasian Studies (ASEEES). The convention, which should have taken place in Washington, was held online on 5-8 and $14-15$ November.

The panel consisted of four presentations: by Maria Whittle (University of California, Berkeley), Dr. J. Alexander Ogden (University of South Carolina), Dr. Alexander Nikulin (RANEPA and MSSEES, Moscow) and Eliane Fitzé (University of Fribourg, Switzerland). The papers were commented by two discussants - Prof. Em. Kathleen Parthé (University of Rochester) and Dr. Irina Trotsuk (RUDN and RANEPA, Moscow).

The issues of the Russian peasantry and notions of 'Russianness' have accompanied each of us in our respective fields of research - from literary studies to sociology. Thus, the idea was to consider the phenomenon more broadly, in different perspectives, from the nineteenth century until today. Together, we discussed different ways in which the Russian peasant has served as a reference figure for speaking about identity, the country's past, present and future. The general convention theme was "Anxiety and Rebellion", which fitted the panel's topic well: throughout the Russian history, the concept of rurality has enjoyed popularity through periods of anxiety, when the malaia rodina ('little homeland'), the peasant family and its traditional way of life, and the village community were places of longing in times of change and uncertainty. 
The panel started with the presentation on the nineteenth-century poet Aleksei Koltsov, to whom Alexander Ogden dedicated his paper "Anxieties of influence: The imagined narod in reception of A.V. Koltsov's literary imitations of folk verse". Koltsov was and is generally considered the most significant peasant poet of the nineteenth century. However, as Alexander Ogden showed, this attribution was not as self-evident as we might think: in fact, Koltsov was not even a peasant, but had grown up as part of the Voronezh meshchanstvo and followed in his father's footsteps by working as a prasol, a cattle dealer. Koltsov's contemporaries were well aware of this fact, but it did not stop them from believing in the purity and authenticity of Koltsov's peasant poetry, for he still stood very close to the narod in their perception. It was only after his death that this perception changed, and the peasant voices in his poetry were increasingly read as the poet's own voice. Thus began the posthumous fashioning of Koltsov as the most authentic and 'pure' peasant poet.

Moving chronologically, the panel turned to the early Soviet-Russian literature with Eliane Fitzé's presentation entitled "Reviving ruralness in post-revolutionary Russian literature: Aleksandr Chayanov's and Apollon Karelin's peasant utopias". The presenter took a closer look at Chayanov's The Journey of My Brother Alexei to the Land of Peasant Utopia (1920) and Karelin's Russia in 1930 (1921). The ideological background to these two works could hardly differ more: Chayanov's utopia is a socialist peasant republic with strong peasant cooperatives and regulating state, while Karelin's utopia presents Russia in 1930 as an anarchist country without any statehood. Nevertheless, both authors imagine a future Russia as based on rural forms of living and working. To explain this, both utopias focus on peasant labor, real peasant work in the field, as well as economic features of peasant life. In the positive depiction of peasant labor, Russia's agrarian nature looks not as a hinderance in the country's path to a brighter future, but, on the contrary, as an asset.

Maria Whittle's paper was entitled "'A synonym for salvation': Siberian identity and national vision in late-Soviet village prose". She focused on Valentin Rasputin's 1983 essay "Siberia without the Romance" as a case for exemplifying the complex dynamics of regional identity and national belonging in the Siberian village prose. As Maria Whittle showed, it was exactly by focusing on regional experience that Rasputin envisioned possible paths to the future for Russia: literature becomes a means of access to a feeling of reverence for Russia's natural riches for the reader alienated from nature. By this feeling, Rasputin invites the observer to participate in the perception from within, to self-identify with rural Russia, to experience Russianness through literature.

Alexander Nikulin talked about his empirical research and notions of peasantness in his presentation "Imagined peasantry in contemporary Russia". Even though peasants in the traditional sense had dis-

\section{E. Fitzé}

Interdisciplinary panel on the Russian peasantry and notions of 'Russianness', at the Annual Convention of the Association for Slavic, East European, and Eurasian Studies (ASEEES), 8 November 2020 
200 appeared from Russia's countryside during the tragic events of the twentieth century, the last decades have shown a renewed interest in the peasantry. Indeed, different social strata of the Russian society have been expressing sympathy to the peasantry - in monuments, mass media and folklore. However, a closer look at these phenomena reveals that there is little interest in the development of the countryside. Rather the peasantry, or ruralness in general, is instrumentalized for political goals (such as to win local or regional elections) or economic gain (such as when the large agribusiness presents its industrial products as if produced by idyllic rural family farms). At the same time, Alexander Nikulin's field work shows attempts of revitalizing the peasantry, such as the increasingly self-confident dacha movement, development of eco-farms that try to rediscover traditional peasant technologies and combine them with new technologies, or the growing interest in rural local lore and booming agritourism. Alexander Nikulin believes that future developments will run along the same vein: there is a growing number of eco-villages, a boom in traditional rural architecture, and dreams of regional self-government and self-representation. Thus, contemporary Russia not only tries to remember rural traditions and imitate the peasantry, but also to reinvent and discover new ways of peasant development in its countryside.

Both discussants welcomed all four papers and presentations. Kathleen Parthé, whose feedback was received before the session, considered the papers from a literary point of view and re-embedded them in the respective literary and cultural contexts based on her immense knowledge of the Russian literature in general and of the peasant theme in literature in particular. Especially fruitful were her insights on Alexander Herzen's works as linked to both Chayanov's utopia and receptions of Koltsov. Moreover, her comments reassured the presenters' findings and substantiated them with her profound knowledge of village life and of how literature tries to evoke genuine Russianness in different ways. Irina Trotsuk identified three 'dimensions' in the issue of Russianness and peasantness in contemporary Russia: political-economic, social-economic, and cultural. She situated all four presentations within these three dimensions and drew parallels between them and today's discourses on the Russian countryside, for example, on the way in which authenticity and 'knowing the people' is still as important in the perception of official figures as it was during the time of Koltsov's life and work.

The panel ended with a fruitful (and still ongoing) discussion on the role of the peasantry in imagining the Russian nation. All participants agreed that this discussion could be led only from different points of views, and in different disciplinary perspectives. The reason is the complex nature of the 'imagined community' (Benedict Anderson) of Russia. Over centuries, the debates on Russianness have taken place only in the sphere of culture, which is why literature still serves as a valuable access to the peasant theme and its significance 
for discussing the Russian national identity. However, literary studies 201 rely on other disciplines in order to access questions that are framed poetically but go back to matters of other fields of research, such as social anthropology, sociology or history. Therefore, the panel's participants would like to pursue this interdisciplinary approach combining literary studies and sociology in order to understand the relationship between Russianness and ruralness on its different levels and in its different meanings.

\section{Междисциплинарная секция, посвященная российскому крестьянству и трактовкам "русскости", на Ежегодной конференции Ассоциации славянских, восточноевропейских и евразийских исследований (ASEEES), 8 ноября 2020 года}

Элиан Фитзе, аспирант кафедры славянской литературы в Университете Фрибург (Швейцария). Рю ду Крибле 13, 1700, Фрибург, Швейцария.E-mail: eliane.fitze@unifr.ch.

\section{E. Fitzé}

Interdisciplinary panel on the Russian peasantry and notions of 'Russianness', at the Annual Convention of the Association for Slavic, East European, and Eurasian Studies (ASEEES), 8 November 2020 